\title{
Influence of Paclobutrazol on Growth and Flowering of Rhododendron 'Sir Robert Peel'
}

\section{R.I. Wilkinson ${ }^{1}$ and D. Richards ${ }^{2}$ \\ Horticultural Research Institute, Knoxfield, Department of Agriculture and Rural Affairs, P. O. Box 174, Ferntree Gully, Victoria, Australia}

Additional index words. ICI-PP333, growth retardants

Abstract. Shoot extension of Rhododendron 'Sir Robert Peel' was reduced, but flowering was more precocious after treatment of plants with paclobutrazol. All of the drench rates tested ( 0.05 to $0.4 \mathrm{~g}$ a.i./pot) proved excessive and resulted in prolonged shoot growth reduction but greatly increased the number of flowers. However, flowers produced at the higher drench rates were grossly malformed and unacceptable. Foliar spray treatments (250 to $2000 \mathrm{mg}$ a.i./liter) were less inhibitory than drenches, and a single spray of $500 \mathrm{mg} \cdot$ liter $^{-1}$ was considered an appropriate commercial application rate. Paclobutrazol application could thus prove to be a useful technique in producing compact flowering plants of Rhododendron hybrids for improved retail sales. Chemical name used: B-[(4 chlorophenyl) methyHo-(1,1-dimethylethl)-1H-1,2,4-triazole-l-ethano1 (paclobutrazol, ICI-PP333).

Many Rhododendron hybrids have large terminal clusters of flowers (Bailey, 1942) and, in addition to their frequent use as landscape plants, offer great potential as flowering pot plants. However, numerous cultivars take 3 or 4 years (six or eight growth flushes) to flower after striking from cuttings and produce long woody internodes that detract from their appearance and salability. To fully exploit the potential of Rhododendron hybrids for improved retail nursery sales, shoot length must be controlled and flowering advanced.

Paclobutrazol, a highly active gibberellin (GA) biosynthesis inhibitor (Dalziel and Lawrence, 1984), has been reported to retard stem elongation and, in some instances, to

Received for publication 20 Mar. 1990. The cost of publishing this paper was defrayed in part by the payment of page charges. Under postal regulations, this paper therefore must be hereby marked advertisement solely to indicate this fact.

'Research Officer.

'Section Leader, ornamental plants. thesis inhibitors have also promoted flowering in Rhododendron spp. (Criley, 1985; Halevy, 1983). The purpose of this investigation was to test the efficacy of paclobutrazol to compact the growth of and to advance flowering in Rhododendron 'Sir Robert Peel'. Plants, $50=\mathrm{cm}$ tall and in their 2nd year from cuttings, were established in 20-cm (4.3liter) pots. The potting medium was composed of 3 pine bark : 1 sandy loam : 1 coarse sand (by volume), with fertilizer added at the rate of $3 \mathrm{~kg}$ dolomite, $1.5 \mathrm{~kg}$ Micromax (Sierra Chemical Co., Milpitas, Calif.), and $0.6 \mathrm{~kg}$ iron oxide $/ \mathrm{m}^{3}$ of mix. After 5 months, each pot was topdressed with $18 \mathrm{~g}$ slow-release Osmocote (18N-4.8P-8.3K) and $6 \mathrm{~g}$ Micromax. Plants were grown for the duration of the study (16 months) in a shadehouse under $50 \%$ shade (maximum light level $850 \mu \mathrm{mol} \cdot \mathrm{s}^{-1} \cdot \mathrm{m}^{-2}$ photosynthetic photon flux).

New shoots of Rhododendron normally make two distinct growth flushes in a season-one in spring and another between midsummer to autumn. In mature plants, autumn-flush shoots will normally terminate with a single flower bud (Bailey, 1942). Cathey (1965) reported that Rhododendron required two to three growth flushes before they were responsive to the growth retar- promote flowering in woody ornamental plants (Bailey et al., 1986; Goultson and Shearing, 1985; Wilkinson and Richards, 1988). Other growth regulators known to be GA biosyn-

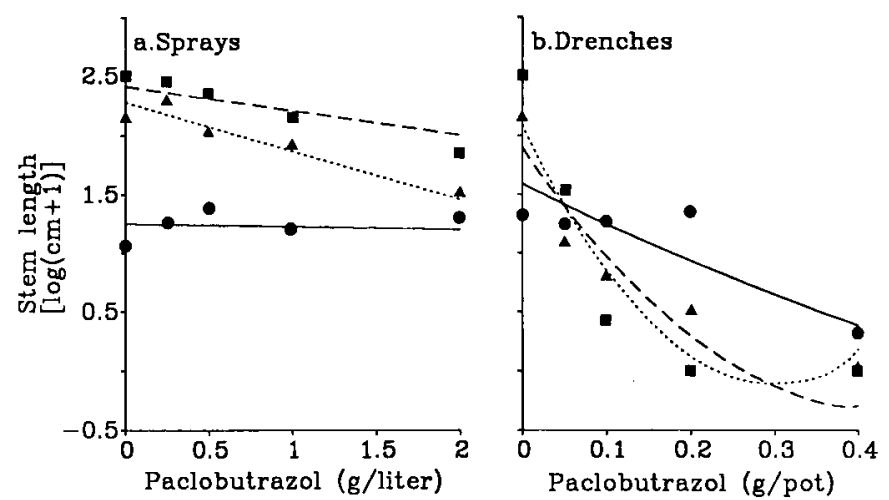

Fig. 1. Influence of paclobutrazol on rhododendron stem extension growth after the third $(\boldsymbol{c}$, week 14), fourth ( $\boldsymbol{\square}$, week 41$)$, and fifth ( $\mathbf{\Lambda}$, week 58) shoot growth flushes. Data were analyzed using multivatiate regression analysis (significant at $P=0.01$ ). (a) Foliar spray treatments regression equation: $\mathrm{Y}=-0.01+0.106 \mathrm{X}_{1}-0.00115 \mathrm{X}_{1}{ }^{2}-0.00012 \mathrm{X}_{1}{ }^{2} \mathrm{X}_{2}, r=0.85^{* *}$. (b) Media drench treatments regression equation: $\mathrm{Y}=1.434+0.0113 \mathrm{X}_{1}-0.258 \mathrm{X}_{1} \mathrm{X}_{2}+0.0076 \mathrm{X}_{1}{ }^{2} \mathrm{X}_{2}^{2}, r=$ $0.81^{* *}$, where $Y=\log _{10}$ (centimeter +1$), X_{1}=$ weeks, and $X_{2}=$ paclobutrazol dose. 

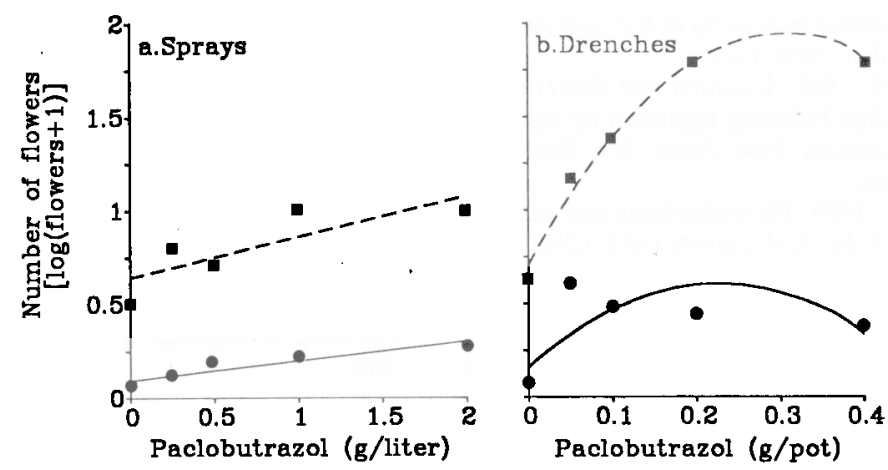

Fig. 2. Influence of paclobutrazol on the number of flowers produced per rhododendron plant during first ( $\bullet$, week 32) and second ( $\boldsymbol{\square}$, week 66$)$ flowering seasons after treatment. Data were analyzed using multivariate regression analysis (significant at $P=0.01$ ). (a) Foliar spray treatment regression equation: $Y=-0.423+0.0162 \mathrm{X}_{1}+0.0033 \mathrm{X}_{1} \mathrm{X}_{2}, r=0.74$. (b) Media drench treatments regression equation: $\mathrm{Y}=-0.354+0.016 \mathrm{X}_{1}+0.124 \mathrm{X}_{1} \mathrm{X}_{2}-4.37 \mathrm{X}_{2}^{2}-0.139 \mathrm{X}_{1} \mathrm{X}_{2}^{2}, r=0.89$, where $Y=\log _{10}$ (flower number +1$), X_{1}=$ weeks, and $X_{2}=$ paclobutrazol dose.
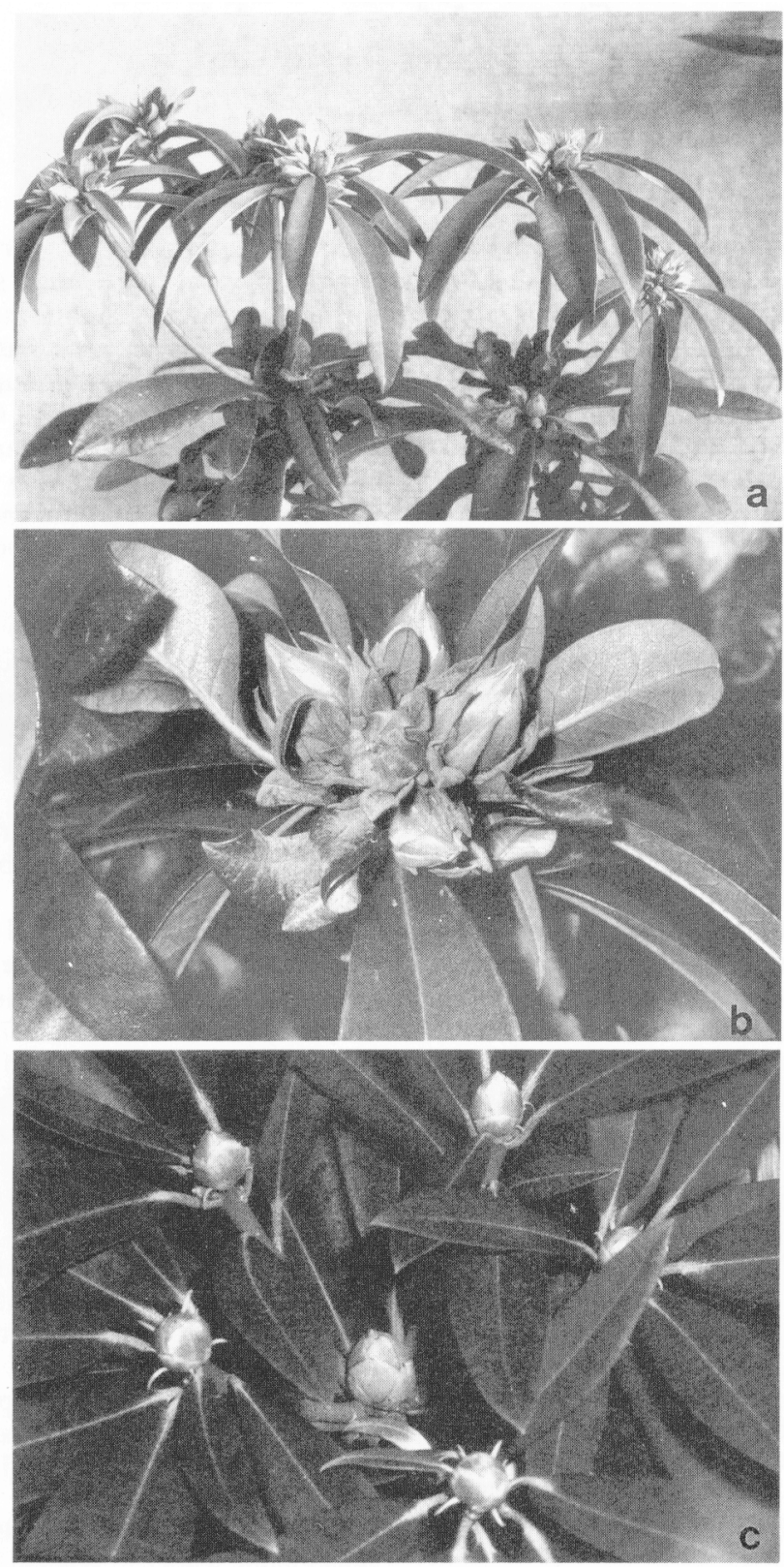

Fig. 3. The appearance of flower buds produced in the second season after treatment. (a) Multiple buds in terminal rosettes on plants treated with $0.2 \mathrm{~g}$ a.i. paclobutrazol/pot. (b) Close-up of (a) showing distorted, malformed buds. (c) Single terminal buds produced on plants sprayed with 500 $\mathrm{mg}$ paclobutrazol/liter. dants phosphon and B-Nine, which increased flowering. Thus, in the present study, the plants were left to commence their third flush in autumn, when new shoots were 15 $\mathrm{cm}$ long, before the treatments were imposed (week 0). Paclobutrazol was applied as a suspension, either as a single foliar spray at rates of $0,250,500,1000$, and 2000 $\mathrm{mg} \cdot 1$ iter $^{-1}$ (a.i.) applied to run-off or as a single 200-ml drench applied to moist medium at $0,0.05,0.1,0.2$, or $0.4 \mathrm{~g}$ a.i./pot. The experimental design was a completely randomized block with five single-plant replicates per treatment.

Growth measurements were made after 14 , 41 , and 58 weeks, which represented the end of the third, fourth, and fifth growth flush, respectively. On each occasion, the total shoot length of each growth flush was measured. The number of flower buds-were recorded for each plant after 32 and 66 weeks. Some flower buds were selected at rafidom fermicroscopic examination of floral development. All data was analyzed by multivariate regression analysis.

None of the foliar applications had an effect on the third growth flush (autumn, week 14), but shoot extension of the subsequent flushes (spring, week 41 and autumn, week 58) showed a linear decline with increasing spray concentration (Fig. la). The reduction in shoot extension was greater in the fifth flush than in the fourth flush, but in both cases a desirable reduction $(\approx 30 \%)$, relative to the control, was obtained with the spray at $500 \mathrm{mg} \cdot 1$ iter $^{-1}$.

Media drenches of paclobutrazol reduced shoot extension to a greater extent than foliar sprays. In all growth flushes, the dose response showed a curvilinear decline in shoot length with increasing drench rate (Fig. lb). Shoot extension was almost totally suppressed by the higher drench rates $(0.2$ and $0.4 \mathrm{~g} / \mathrm{pot})$, particularly in the fourth and fifth growth flushes. The greater growth reduction of drenches compared to sprays could be due to a build-up of paclobutrazol in shoot meristems. Dalziel and Lawrence (1984) have proposed that paclobutrazol will move to apical meristems if applied to roots, whereas foliar application results in minimal translocation from leaves.

There was a small but significant $(P=$ $0.01)$ linear increase in the number of flowers on the third growth flush (week 32) with increasing spray concentration (Fig. 2a). For the 2000-mg-liter-' spray treatment, three of the five replicate plants flowered after 32 weeks, compared to only one of five plants in the control. A steeper linear increase in the number of flower buds with spray concentration was observed in the fifth growth flush (week 66). All paclobutrazol-treated plants produced some flower buds after 66 weeks, but only four of the five control plants flowered.

The relationship between number of flower buds and drench rate was curvilinear, with the response reaching a plateau between 0.2 and $0.4 \mathrm{~g} /$ pot (Fig. 2b). After the third growth flush (week 32), the number of flower buds was about doubled for all drench rates com- 
pared to the control. Most importantly, four of the five replicate plants flowered for each paclobutrazol treatment, whereas only one of the five control plants flowered. The curvilinear relationship between drench rate and flowering was more pronounced in the fifth growth flush (week 66). Even the lowest drench rate $(0.05 \mathrm{~g} / \mathrm{pot})$ produced five times the number of flower buds present on control plants. The highest drench rates $(0.2$ and 0.4 g) resulted in the development of 70 to 80 flower buds, compared with only 3 to 4 flower buds on control plants.

The morphology of the flowering response, however, was greatly affected by the paclobutrazol dose. Plants drenched with $\geqslant 0.1 \mathrm{~g}$ paclobutrazol produced rosettes of flower buds on the terminal regions of all shoots (Fig. 3 a and b). Microscopic examination showed that these buds contained only rudimentary floral parts and did not flower normally. By contrast, the control plants, those drenched with $0.05 \mathrm{~g}$, and all of the foliar-treated plants produced single, wellformed terminal flower buds (Fig. 3c). The abnormal flowering pattern at high drench rates could be related to the adverse effects of prolonged exposure to high levels of paclobutrazol residing in the apical tissues. This supposition is supported by reports that GA application promotes flower maturation in Rhododendron (Criley, 1985). Interference with endogenous GA levels may disturb the normal pattern of flower bud development. Further studies on the factors affecting bud development under the influence of high paclobutrazol levels is therefore warranted.

Since GA inhibits flower initiation in Rhododendron (Criley, 1985) and paclobutrazol is reported to block GA biosynthesis (Dalziel and Lawrence, 1984), increased flowering of treated plants was not unexpected. The present results also show that paclobutrazol at high concentrations reduced the vegetative phase in Rhododendron and advanced flowering by 1 year.

The present study highlights that any commercial users of paclobutrazol on Rhododendron hybrids will need to consider the method of application and the desired balance between growth control and flowering. In Rhododendron 'Sir Robert Peel', drenches (even at the lowest rate of $0.05 \mathrm{~g}$ a.i./pot) caused excessive and prolonged reductions in shoot growth. Higher drench rates had the confounding effect of producing numerous but malformed flower buds.

Single foliar sprays gave more acceptable results. Spray concentrations of paclobutrazol between 500 to $2000 \mathrm{mg} \cdot$ liter- $^{1}$ all produced acceptable compact flowering plants. We considered the 500-mg.liter ${ }^{-1}$ treatment the most suitable for commercial use because it achieved the most desirable balance between growth reduction and increased flowering.

\section{Literature Cited}

Bailey, D. A., T.C. Weiler, and T.I. Kirk. 1986. Chemical stimulation of floral initiation in florists hydrangea. HortScicncc 21 (2):256-257.

Bailey, L.H. 1942. Rhododendron, p. 293\&2948.
In: The standard cyclopedia of horticulture. vol. 3. Macmillan, New York.

Cathey, H.M. 1965. Initiation and flowering of Rhododendron following regulation by light and growth retardants. Proc. Amer. Soc. Hort. Sci. 86:753-760.

Criley, A.R. 1985. Rhododendrons and azaleas, p. 180-197. In: A.H. Halevy (cd.). CRC handbook of flowering. vol. 4. CRC Press, Boca Raton, Fla.

Dalziel, J. and D.K. Lawrence. 1984. Biochemical and biological effects of Kaurene oxidase inhibitors, such as paclobutrazol. Brit. Plant Growth Regulat. Group, Monogr. 11.

Goultson, G.H. and S.J. Shearing. 1985. Review of the effects of paclobutrazol on ornamental pot plants. Acts Hort. 167:339-348.

Halevy, A.H. 1983. Regulation of flowering in flower crops by growth substances. Acts Hort. 147:193-198.

Wilkinson, R.I. and D. Richards. 1988. Influence of paclobutrazol on growth and flowering of Camellia $\times$ williamsii. HortScience 23(2):359360. 